\title{
Geotechnical Properties of Fly Ash and its Application on Soft Soil Stabilization
}

\author{
Emilliani Anak Geliga ${ }^{1}$ and Dygku Salma Awg Ismail ${ }^{2}$
}

\begin{abstract}
Soil stabilization has become the major issue in construction engineering and the researches regarding the effectiveness of using industrial wastes as a stabilizer are rapidly increasing. This paper briefly describes the suitability of the local fly ash to be used in the local construction industry in a way to minimize the amount of waste to be disposed to the environment causing environmental pollution. Several civil engineering laboratory tests are conducted to study the geotechnical properties of fly ash and strength gain when mixed with local clay sample. A different proportion of fly ash and soil sample cured for 7 days results in a strength gain. A better understanding of the properties of fly ash is gained from the study and the tests indicates an improved strength and better properties of soft soil sample when stabilized.
\end{abstract}

Keywords: fly ash , soft soil, stabilization

\section{INTRODUCTION}

$\mathrm{C}$

ivil engineering projects located in areas with soft or weak soils have traditionally incorporated improvement of soil properties by using cement and lime. Use of fly ash as a ground improvement soil admixture, when found viable, will be effective in terms of cost and a good approach to the environment to preserve and minimize accumulation of industrial waste. This study is performed to obtain geotechnical properties of fly ash for its application in the stabilization of soft soil. The geotechnical properties of fly ash will be evaluated with various laboratory tests to investigate the feasibility of using fly ash in soft soil stabilization. Constructions over soft soil are one of the most frequent problems in many parts of the world. The typical approach to soil stabilization is to remove the soft soil, and substitute it with a stronger material of crushed rock. Due to substantial cost of replacement, alternative methods to the problems are assessed. The study of using coal combustion residues, fly ash, is carried out to observe the effectiveness of its addition on stabilization of soft soil. This is one of the approaches to overcome the increasing amount of solid waste generated by the population. As land is a very valuable commodity and landfills are fast diminishing, the disposal of the ash generated from solid waste incineration poses increasingly difficult problems for the municipalities. A practicable solution to the disposal problems would be the reuse of solid waste ash for civil engineering applications. A research study of the geotechnical properties of the incinerator fly ash derived from solid waste incineration is investigated. The objectives of the study are to determine the geotechnical properties of fly ash and to investigate the effects of fly ash addition for strength of stabilized soft soil. Scope of this study is to analyze the consequences of the application of fly ash in soft soil stabilization. It covers methods for determining the geotechnical properties of fly ash to assess its suitability for soft soil stabilization. The fly ash is taken from Sejingkat Thermal Plant, Kuching.

\section{LITERATURE REVIEW}

Fly ash is one of the most plentiful and industrial by-products. It is generated in vast quantities as a by-product of burning coal at electric power plants (Senol et al., 2006). Electric utility companies in many parts of the world generate electricity by burning coal which generate an amount of fly and bottom ash. Fly ash generated by coal combustion based power plants typically fall within the ASTM fly ash classes C and F (Reyes and Pando, 2007). Fly ash consists of inorganic matter present in the coal that has been fused during coal combustion. This material is solidified while suspended in the exhaust gases and is collected from the exhaust gases by electrostatic precipitators. Since the particles solidify while suspended in the exhaust gases, fly ash particles are generally spherical in shape (Ferguson et. al., 1999). Fly ash particles those are collected in electrostatic precipitators are usually silt size $(0.074-0.005 \mathrm{~mm})$. Making a more productive use of fly ash would have considerable environmental benefits, reducing air and water pollution. Increased use as a partial cement or lime replacement would also represent savings in energy because fly ash has been called a high-energy-based material (Hausmann, 1990). Fly ash utilization, especially in concrete, has significant environmental benefits including (FHWA, 2006):

i. Increasing the life of concrete roads and structures by improving concrete durability,

${ }^{I}$ Student, Department of Civil Engineering, Faculty of Engineering, Universiti Malaysia Sarawak, 94300-Kota Samarahan, Sarawak, Malaysia.

${ }^{2}$ Lecturer, Department of Civil Engineering, Faculty of Engineering, Universiti Malaysia Sarawak, 94300-Kota Samarahan, Sarawak, Malaysia, $+6082583268$ 
ii. Net reduction in energy use and greenhouse gas and other adverse air emissions when fly ash is used to replace or displace manufactured cement,

iii. Reduction in amount of coal combustion products that must be disposed in landfills,

iv. Conservation of other natural resources and materials.

\section{Atterberg Limits}

Soils containing fines display the properties of plasticity and cohesiveness where a lump of soil can have its shape changed or remolded without the soil changing in volume or breaking up. This property depends on the amount and mineralogy of the fines and the amounts of water present, or generally known as moisture content. As the moisture content increases clayey soil will become softer and sticker until it cannot retain its shape when it is described as being in a liquid state. If the moisture content is decreased, the soil becomes stiffer until there is insufficient moisture to provide cohesiveness when the soil become friable and cracks or breaks up easily if remolded. This is described as semi - plastic solid or semi - solid. If the moisture content decreased further there is a stage where the forces between the soil particles will not permit them to move closer and now the soil described as a solid. It is very useful to define the moisture content at these transitions between above states. They are determined as liquid limit, plastic limit and shrinkage limit. A Swedish soil scientist named Atterberg, thus the tests now known as Atterberg Limits devised the tests for liquid and plastic limit. Both tests are carried out on the portion of a soil finer than $425 \mu \mathrm{m}$.

\section{Specific Gravity}

The variation of specific gravity of fly ash is the result of a combination of many factors such as gradation, particle shape and chemical composition (Gray and Lin, 1972). This low specific gravity of fly ash results in low dry density. This is because of micro bubbles of air entrapped in ash particles. The trapping of air increases the surface area hence the volume of fly ash. The breaking of fly ash particles increases specific gravity that may be because of release of entrapped gas when ash grounded by mortar and pestle (WEBB, 1973). According to Pandian et al.,(1998) the low specific gravity could be either the presence of more hollow cenospheres from which the entrapped air cannot be removed or the variation in the chemical composition (in particular, iron content) or both.

\section{Mechanical Properties}

\section{Compaction Characteristics}

Compaction characteristics of soil-fly ash mixes were studied by several investigators since they are very important in the construction of embankments, roads, and backfilling of retaining walls. Several investigators reported that the maximum dry unit weight increases and the optimum moisture content decreases due to addition of fly ash (Basavanna and Ravi Kumar 1990, Choudhary 1994, Pandian 2004, Prabakar 2004)

The compaction tests were performed to get the optimum water content and maximum dry unit weight of fly ash sample.

Table 2: Geotechnical Properties of Fly Ash (Gupta, 2008)

\begin{tabular}{|l|l|c|}
\hline No & \multicolumn{1}{|c|}{ Property Name } & Value \\
\hline 1 & $\begin{array}{l}\text { Grain size distribution } \\
\% \text { of Gravel } \\
\% \text { of sand } \\
\% \text { of silt + clay }\end{array}$ & Nil \\
& 6 \\
\hline 2 & Coefficient of Uniformity, $\mathrm{C}_{\mathrm{u}}$ & 94 \\
\hline 3 & Coefficient of Curvature, $\mathrm{C}_{\mathrm{c}}$ & 2 \\
\hline 4 & Specific Gravity & 1.13 \\
\hline 5 & $\begin{array}{c}\text { Direct shear test } \\
\text { Cohesion } \\
\text { Angle of Shear resistance }\end{array}$ & $0.05-2.2$ \\
\hline 6 & $\begin{array}{c}\text { Proctor's Density } \\
\text { Optimum Moisture Content }\end{array}$ & $27^{\circ}$ \\
\hline 7 & Max. Dry Density & $18 \%$ \\
& $\begin{array}{c}\text { Permeability Test } \\
\text { Coefficient of Permeability }\end{array}$ & $1.29 \mathrm{~g} / \mathrm{cc}$ \\
\hline & $\quad$ & $1.3 \times 10^{-4} \mathrm{~cm} / \mathrm{sec}$ \\
\hline
\end{tabular}

\section{Compressive strength}

Based on Reyes and Pando (2007), the compressive strength of tested plain fly ash for 7 days curing period gives 4754 $\mathrm{kN} / \mathrm{m}^{2}$. The compressive strength values indicate that all admixture treatment types resulted in strength gains and that most of the gain occurred within the first seven days of curing. The fast strength gain is believed to be related to the initial rapid 
hydration that takes place with the admixture. The strength gain due to stabilization depends mainly upon three factors; ash content, molding water content and compaction delay (Senol et al 2006).

Fly ash has been used successfully in many projects to improve the strength characteristics of soils. Fly ash can be used to stabilize bases or subgrades, to stabilize backfill to reduce lateral earth pressures and to stabilize embankments to improve slope stability. Typical stabilized soil depths are 15 to 46 centimeters ( 6 to 18 inches). The primary reason fly ash is used in soil stabilization applications is to improve the compressive and shearing strength of soils. The compressive strength of fly ash treated soils is dependent on:

- In-place soil properties

- Delay time

- Moisture content at time of compaction

- $\quad$ Fly ash addition ratio

\section{Hydration of Fly Ash}

Formation of cementitious material by the reaction of free lime $(\mathrm{CaO})$ with the pozzolans $\left(\mathrm{AlO}_{3}, \mathrm{SiO}_{2}, \mathrm{Fe}_{2} \mathrm{O}_{3}\right)$ in the presence of water is known as hydration. The hydrated calcium silicate gel or calcium aluminate gel (cementitious material) can bind inert material together. Hydration of tricalcium aluminate in the ash provides one of the primary cementitious products in many ashes. The rapid rate at which hydration of the tricalcium aluminate occurs results in the rapid set of these materials, and is the reason why delays in compaction result in lower strengths of the stabilized materials. The hydration chemistry of fly ash is very complex in nature. So the stabilization application must be based on the physical properties of the ash treated stabilized soil and cannot be predicted based on the chemical composition of the fly ash (Wikipedia, 2008)

\section{METHODOLOGY}

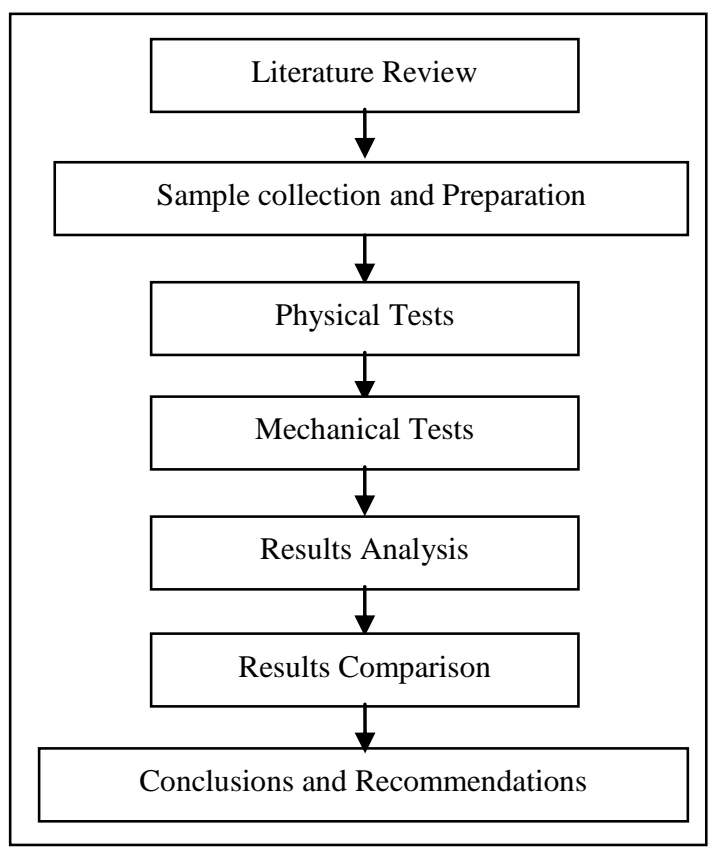

Figure 1: Flowchart of Methodology

The overall flow of research is as illustrated in Figure 1. The tests were conducted in accordance with British Standard 1377. Several physical tests had been conducted for clay sample, fly ash sample and mixes of clay and fly ash. The tests mentioned were Atterberg Limits test, Specific Gravity test, sieving and hydrometer test. In Atterberg Limit tests, Liquid Limit (LL) and Plastic Limit (PL) were obtained. Then, Plasticity Index was determined based on Plasticity chart (BS 5930:1981). The LL of clay and fly ash mixes is obtained by testing varies of fly ash percentage. Specific gravity and particle size distribution are obtained for original fly ash and clay sample. In addition, Standard Proctor and Unconfined Compressive Tests were conducted in order to obtain geotechnical properties of the sample. Unconfined compressive strength for clay and fly ash mixes is obtained based on cured sample for 7 days. 


\section{RESULTS AND DISCUSSIONS}

In Table 3, the values were obtained from laboratory tests indicate the geotechnical properties of Fly ash, the physical properties and mechanical properties.

Table 3 : Engineering Properties of Fly ash

\begin{tabular}{|l|c|}
\hline Geotechnical Properties & Value \\
\hline Liquid Limit & 22.5 \\
\hline Plastic Limit & 6.17 \\
\hline Plasticity Index & 16.33 \\
\hline Specific Gravity & 2.17 \\
\hline Optimum Moisture Content & $15.4 \%$, \\
\hline Maximum Dry Density & $1.51 \mathrm{~kg} / \mathrm{m}^{3}$ \\
\hline 7 Days Compressive Strength & $82.53 \mathrm{kPa}$ \\
\hline
\end{tabular}

Figure 2 show the particle size distribution of clay sample and Fly ash. It shows that the Clay sample fall under the silt category and is gap graded i.e the particle size is a combination of 2 or more uniformly graded fraction. While Fly ash is of a poorly graded fine particles i.e the particle of Fly ash is of the same size.

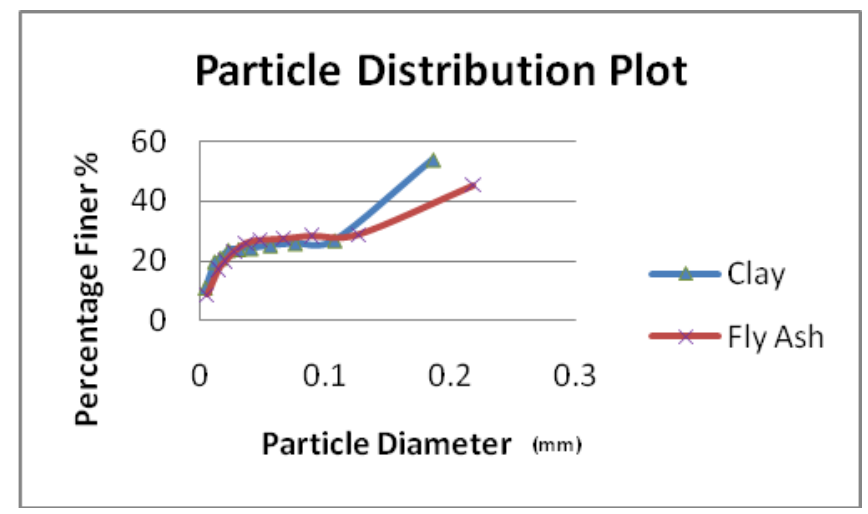

Figure 2: Particle Size Distribution of Clay sample and Fly Ash

From Table 4 it can be seen that the liquid limit of the sample is decreasing with the increasing amount of Fly Ash with the percentage of $0 \%, 5 \%, 10 \%, 15 \%$ and $20 \%$.

Table 4: Liquid Limit of different Percentage of Fly Ash by weight in Clay

\begin{tabular}{|c|c|}
\hline $\begin{array}{c}\text { Percentage of Fly Ash by } \\
\text { weight in Clay }\end{array}$ & Liquid Limit , \% \\
\hline $0 \%$ & 60 \\
\hline $5 \%$ & 57.5 \\
\hline $10 \%$ & 55 \\
\hline $15 \%$ & 56 \\
\hline $20 \%$ & 51 \\
\hline
\end{tabular}

The sample of clay and Fly Ash mixes of 0\%, 60\% 80\% and 100\% were cured for seven (7) days. Figure 3 shows the stress strain characteristics of the samples observed in Unconfined Compressive strength test. The $60 \%$ Fly Ash by weight of clay results is the highest value of compressive strength, while Fly Ash alone is not a very strong material. 


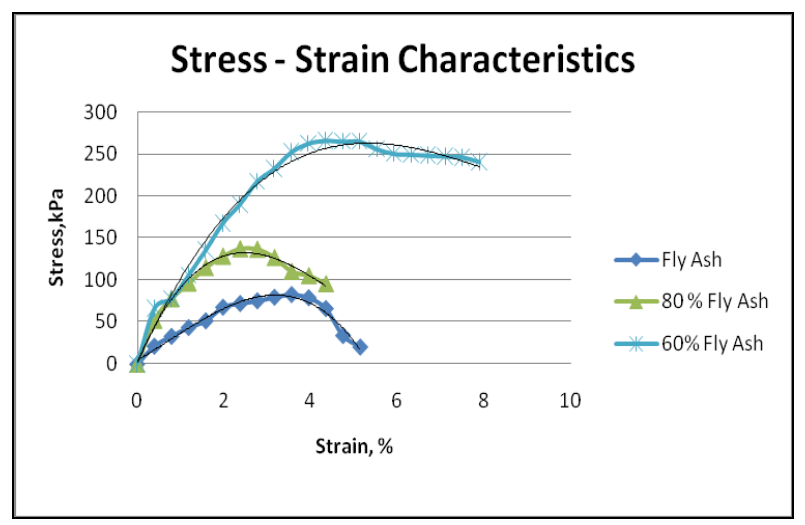

Figure 3: Stress - Strain Characteristics

Figure 4 shows the shear stress with respect to percentage if fly ash in clay sample. From Figure 4 , the declined line shows that when there is too much amount of fly ash added, the shear stress is decreased as the sample was not able to stand the amount of stress applied. $60 \%$ of fly ash by weight of clay in the clay mixture gave the highest value of axial stress exerted. The fly ash alone is not a very strong material. The shear strength of cured sample tested was within the limitation based on the dry density and optimum moisture content of the fly ash which is $1.51 \mathrm{~kg} / \mathrm{m}^{3}$.

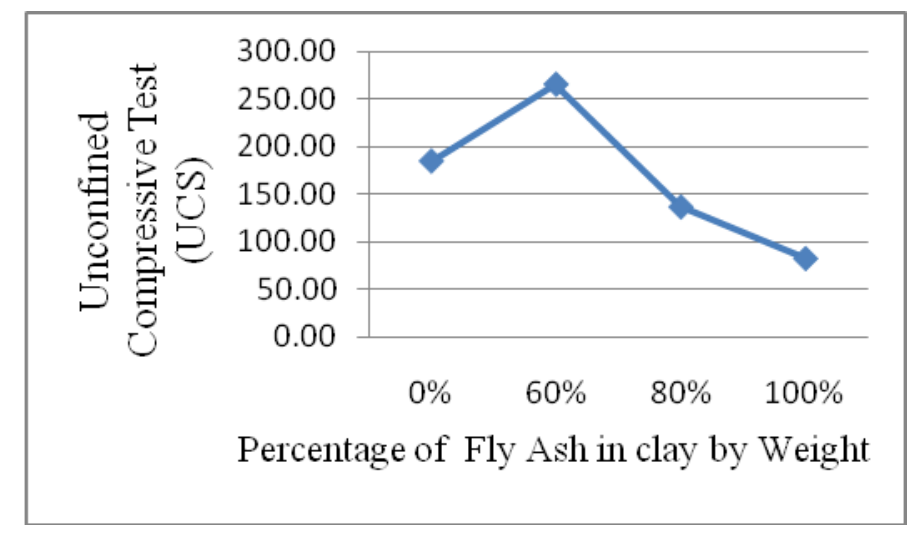

Figure 4: Unconfined Compressive Test versus different percentage of fly ash and clay mixes.

\section{CONCLUSION}

1. From the study, finally the basic Geotechnical Properties of Fly Ash can be concluded in the following table of 5.1. From the classification tests, the clay is classified as Gravelly clay. The Fly Ash is ashes with very fine particles slightly smaller than the particle size of clay. The different size can create a good bonding between the clay particle and Fly Ash particles. This type of clay is suitable to be stabilized with Fly Ash.

2. Addition of Fly Ash does have effects on the strength of clay. The shear strength observed of sample mixtures cured for 7 days were decreasing when amount of fly ash governed $80 \%$ of the total weight of mixture. Besides that, $60 \%$ of fly ash by weight and clay mixture gave the highest value of axial stress exerted. The fly ash alone is not a very strong material. Therefore in this scope of study, the most suitable amount of fly ash to be added in fly ash and clay mixes is between $50 \%$ $60 \%$. Besides the shear strength, the addition of fly ash also does improve other properties such as the dry density of mixture soil and the optimum moisture content of soil.

\section{RECOMMENDATIONS}

i. It is recommended that a longer curing period should be done for $7,14,21 \& 28$ days in order to observe the shear strength pattern of fly ash and clay mixture of different mixture.

ii. It is also recommended that the liquid limit of cured samples should be done since in this study only the liquid limits of uncured treated samples were done. 
iii. For further study it is suggested that the Consolidation Test to be performed to attain the compressibility of samples and to obtain soil data which is used in predicting the rate and amount of settlement of structures founded on clay.

iv. It is also proposed to run the X-ray diffraction (XRD) to obtain the chemical composition of FA in order to determine the type of Fly Ash accurately.

v. For advance research, it is recommended that the effect of combining two stabilizing agents in the stabilization of soft soil to be investigated to see whether it can improve the properties of soil better than fly ash alone.

\section{ACKNOWLEDGMENT}

The authors wish to thank Laboratory Assistances, Faculty of Engineering, UNIMAS Geotechnical Engineering Lecturers and fellow coursemates.

\section{REFERENCES}

[1] American Society of Civil Engineers (ASCE) (2003), 'Fly Ash'” http://engineers.ihs.com/pdf/abstact-navigation.html, September 17 2008.

[2] Basavanna, B.M. and Itagi Ravi Kumar (1990) 'Use of Coal Ash to Improve Some Properties of Black Cotton Soil,' Indian Geotechnical Confrence1990 on Advances in Geotechnical Engineering, Indian Geotechnical Society, Bombay, India, pp. 185 - 188.

[3] Das, B.M., (2002), Principles of Geotechnical Engineering, Fifth Edition, Australia; Brooks/Cole.

[4] Ferguson, G. (1993). "Use of self-cementing fly ashes as a soil stabilization agent." Fly ash for soil improvement, Geotechnical Special Publication No. 36, ASCE, New York, 1-14.

[5] Ferguson, G., (1990) Aggregate Bases Constructed with Self Cementing Fly Ash, $9^{\text {th }}$ international Ash Utilization Symposium, Washington, D.C.

[6] Ferguson, G.,(1987) Ferguson, G(1987) Aggregate Bases Constructed with Self Cementing Fly Ash, $8^{\text {th }}$ international Ash Utilization Symposium, Washington, D.C.

[7] FHWA, 2006 FHWA (2006) - US Department of Transportation, Federal Highway Administration, Chapter 1 - Fly Ash Facts for Highway Engineers - Recycling - Pavements.

[8] Gray and Lin, 1972 Gray, D.H., and Lin, Y.K., (1972), 'Engineering Properties of Compacted Fly Ash.'Journal Soil Mechanics Foundation Engineering, ASCE, Vol. 98, pp.361-380.

[9] Gupta, 2008 Gupta, R.D., Alam, J., Mohd. Ahmadullah Farooqi (2008), Elsevier Ltd. 'Effect On CBR Value And Other Geotechnical Properties Of Fly Ash Mixed With Lime And Non-Woven Geofibres'

[10] Hausmann, M.R.(1990),.Engineering Principles Of Ground Modification, Singapore: McGraw-Hill,

[11] Johnson et al. Johnson, W.A., m.Herrin, D.T. Davidson and R.L. Handy, 1988. Soil Stabilization in Highway Design Reference Guide. $5^{\text {th }}$ Edition, McGraw Hill Book New York, pp: 501-548.

[12] Kolias et al., Kolias, S., V. Kasselouri-Rigopoulou, and Karahalio, A., (2004) 'Stabilization Of Clayey Soils With High Calcium Fly Ash And Cement

[13] Naik et al. Naik T.R., Ramme B.W, Kraus R.N., and Siddique, R., (2003). 'Long Term

[14] Pandian et al., Pandian, N.S., RajaSekhar, C., and Sridharan, A., (1998) 'Studies on the Specific Gravity of some Indian Coal Ashes,' Journal of TESTING AND Evaluation, JTEVA. Vol. 26, No.3, pp. 177-186.

Performance Of High Volume Fly Ash Concrete Pavements', ACI Materials Journal, Vol. $100(1-6), 150-154$

[15] Phanikumar and Sharma (2004) "Effect of flyash on Engg properties of ExpansiveSoil” Journal of Geotechnical and Geoenvironmental Engineering Vol. 130, No7, July, pp. 764-767.

[16] Reyes, A. and Pando, M. (2007). ' Evaluation of CFBC fly ash for Improvement of Soft Clays' World of Coal Ash (WOCA), Covington, Kentucky, USA, May $7-10$.

[17] Scott et. al, 2008"Scott M. Mackiewicz, E. Glen Ferguson"; Stabilization of Soil with Self-Cementing Coal AsheS

[18] Senol et al., Senol, A., Edil, T.C., Md. Sazzad Bin Shafique, Hector, A.A., Benson. C.H.(2006). 'Soft Subgrades' Stabilization by Using Various Fly Ashes'. Resources, Conservation and Recycling, 46 (4); 365 - 376.

[19] TPUB(2008),Chapter 18 Soil Stabilization TPUB, 2008 http://www.tpub.com/content/engineering/14070/css/14070_424.htm, Integrated Publishing Inc.,(September, 2008)

[20] WEBB, 1973 Webb, D. L., (1973), The use of Pulverized Fuel Ash in Reclamation Fills.' Proceedings, $8^{\text {th }}$ International Conference on Soil Mechanics and Foundation Engineering (ICSMFE), Vol. 1.2, Moscow, pp. $471-474$.

[21] Wikipedia (2008), www.wikipedia.com/Fly Ash, September 152008. 